\title{
Inter-sectoral Disparity and Marginalization in Marine Fisheries in India
}

\section{R. SATHIADHAS}

Socio Economic Evaluation and Technology, Transfer Division (SEETTD) Central Marine Fisheries Research Institute, P.B.No.1603, Marine Drive North Extension, Ernakulam North P.O., Kochi-682 018, Kerala State, India.

\begin{abstract}
Fisheries policy in the eleventh plan aims at sustainable economic growth, with due concerns on food and nutritional security and supply side responses. The plan accords overarching priorities on bridging the sharpening divides and increasing disparities in all sectors. The socioeconomic framework of the fishing community with structural changes in coastal sector needs successful design and implementation of development programs. This article highlights the sectoral growth of fishing units and their capital investment over the years, change in ownership pattern of means of production, earnings, sectoral disparity, and inequity among marine fisher folk in India. Base material for the analysis includes primary data collected from selected centers of maritime states in India and secondary data on marine fisheries census of CMFRI and other relevant publications.

There has been sizeable growth of $70 \%$ in the mechanized fishing units and about $200 \%$ growth in motorized sector that are technically efficient (over the last 12 years until 2005). However, there has been a downtrend of $43 \%$ in the nonmechanized units (traditional sector) denoting a gradual phasing out of less efficient units. The improved socio-economic status of fishers is reflected by increase in literacy level, reduction in dropouts, and improvement in housing type. The proportion of owner operators in marine fisheries declined over the years with the increasing capital requirement for possessing motorized and mechanized fishing units. The fishermen involved in active fishing is more than the absorbing capacity of the fisheries sector leading to disguised unemployment and has led to lower per capita production, increased pressure on fishing, which results in juvenile catch, large level discards, and thus ultimately causing serious threats to resource sustainability and environmental stability. The nonmechanized sector is providing about $33 \%$ of the employment in active fishing, yet harvesting hardly $7 \%$ of the annual landings, whereas mechanized segment that employs $34 \%$ harvests $70 \%$ of total catch creating wide inter-sectoral income disparity. The annual per capita catch of fisher folk in mechanized segment is more than twice as those of the per capita catch of the motorized segment and nine times of the per capita catch of the nonmechanized (traditional sector) segment clearly signifying growing inter-sectoral disparity in distribution of economic gains. Average annual per capita earnings of fishing laborer range from Rs.13,200 for a motorized dingi with bagnet to
\end{abstract}

*Corresponding Author. Tel: 91-484-2393192

Email : rsathiadhas_seettd@yahoo.com 
Rs. 1,27,200 for a mechanized purse seiner. Significant variation is also observed even within groups of crafts namely trawlers, gillnetters, purseseiners, motorized, and traditional crafts. The analysis indicate that there is high incidence of poverty in the coastal rural sector explicitly revealing that majority of these people still could not get much of the benefits of the economic development taken place in our country.

\section{Introduction}

Fisheries get importance in planners' agenda in view of the fact that it supports a significant section of population recognized as backward sections of society. Fisheries play a pivotal role in our national development programs either on growth terms, contributing to foreign exchange earnings and domestic consumption, or on equity terms in formulation of poverty reduction strategies. The main objectives of fisheries and aquaculture programs of Government of India during the plan periods have been towards enhancing production and productivity, increasing the export of marine products, promoting sustainable development through responsible fisheries, generation of employment, and enhancing welfare of fisher folk and improvement of their socioeconomic status. The socio-economic framework of the community with its structural changes over the years is the base for formulating plans of action focused on target population. The successful design and implementation of development programs are hampered by lack of such information. Further, impact and trickle down effects of the previous efforts by developmental agencies can be gauged by the changes in socioeconomic indicators of beneficiaries. Several studies have highlighted the micro and macrolevel socio-economic conditions of fishermen in our country (Desai \& Baichwal 1960; Gurtner 1960; Sen 1973; Prakasam 1974; George 1974; Selvaraj 1975; Amarasiri Desilva 1977; Lawson 1977; Panikkar 1980; Sathiadhas \& Venkitaraman 1981; Shanbhu Dayal 1981; Pietersz 1983; Platteau 1984; Prasada Rao \& Kumar 1984; Krishna Srinath 1987; Sathiadhas \& Panikkar 1988; Korakkandy Ramakrishnan 1994). Various studies carried out in the context of a developing country like India point out several problems including marginalization of traditional fisher folk, decreasing ownership of crafts and gears, increasing capital intensity, and declining productivity.

\section{Materials and Methods}

Comprehensive usage of data, both secondary and primary, is attempted in this article. The primary database consists of cost and earnings data of different types of fishing units, collected systematically from all the maritime states in India by the Socio Economic Evaluation and Technology Transfer Division of Central Marine Fisheries Research Institute. Secondary data from Marine Fisheries Census of CMFRI and various publications cited herein are also used in the preparation of this article. 


\section{Results and Discussion}

\section{Socioeconomic profile of coastal fishers}

The marine fishery resources of India comprise 2.02 million sq $\mathrm{km}$ of Exclusive Economic Zone with a continental shelf area of 4,91,000 sq. km. Amongst the different maritime states, Gujarat has the longest coast line of $1600 \mathrm{Kms}$ followed by Tamil Nadu (1076 Kms) and Andhra Pradesh (974 Kms). There are 641 fishing villages in Orissa followed by Tamil Nadu (581) and Andhra Pradesh (498). However, with regard to basic fish landing facilities, Tamil Nadu ranks first with 352 centers followed by Andhra Pradesh (271) and Kerala (178). The marine fisher population is concentrated in the East coast of India (59\%) constituting West Bengal, Orissa, Andhra Pradesh, and Tamil Nadu. In the West coast, $17 \%$ of fisher men population is from Kerala alone. Among the maritime states, fisher population is highest in Tamil Nadu (22\%) followed by Kerala. A similar trend is observed in case of distribution of fisher families across the states. An average fisher household in India has a family size of five, ranging from four in Andhra Pradesh, Tamil Nadu, and Pondichery to six in Karnataka and Daman and Diu (Table 1). The coastal fishing villages in India are thickly populated as the fishermen prefer to stay along the coast line owing to the access to the sea. The Coastal Zone Regulations are not strictly adhered to at times with the reluctance of fishers to move away from proximity to the sea. Among the ten maritime states, Kerala is the most densely populated (population per village) state in India (2713 people per village).

Table 1. Profile of Marine Fishermen Population in India (2005)

\begin{tabular}{lcccc}
\hline State & $\begin{array}{c}\text { Fishermen } \\
\text { population }\end{array}$ & $\begin{array}{c}\text { Number of } \\
\text { t1shermen } \\
\text { families }\end{array}$ & $\begin{array}{c}\text { Average } \\
\text { Family size }\end{array}$ & $\begin{array}{c}\text { Average } \\
\text { population/ } \\
\text { fishing village }\end{array}$ \\
\hline West Bengal & 269,565 & 53,816 & 5 & 779 \\
Orissa & 450,391 & 86,352 & 5 & 703 \\
Andhra Pradesh & 509,991 & 129,246 & 4 & 1024 \\
Tamil Nadu & 790,408 & 192,152 & 4 & 1360 \\
Pondichery & 43,028 & 11,541 & 4 & 1537 \\
Kerala & 602,234 & 120,486 & 5 & 2713 \\
Karnataka & 170,914 & 30,176 & 6 & 1096 \\
Goa & 10,668 & 1,963 & 5 & 274 \\
Maharashtra & 319,397 & 65,313 & 5 & 787 \\
Gujarat & 323,215 & 59,889 & 5 & 1229 \\
Daman and Diu & 29,305 & 5,278 & 6 & 1332 \\
\hline Total & $35,19,116$ & 756,212 & 5 & 1099 \\
\hline
\end{tabular}


The literacy rate among fisher folk in maritime states of India was found to be $56.50 \%$ in 2005. (Table 2). In all maritime states, the literacy rate for coastal population is much lesser than the State averages indicating their poor social development index adding to their vulnerability. Among the maritime states, Kerala ranks first in literacy of marine fisher folk with $72.84 \%$, which is also lower than State literacy rate of $90.86 \%$ (Census 2001). It is observed that $50.70 \%$ of the fisher folk (excluding children) are educated up to primary level, followed by $39.40 \%$ upto secondary and $9.90 \%$ above secondary level education. In contrast to previous trend of huge drop outs from education after primary level, above $50 \%$ of the fisher folk studied beyond primary level. This shows that once fisher folk get exposed to education, they are inclined to get educated to higher levels as seen in most of the maritime states provided there is availability of educational infrastructural facilities.

Table 2 Literacy status of marine fisher folk in India (2005)

\begin{tabular}{|c|c|c|c|c|c|c|}
\hline \multirow[t]{2}{*}{ State } & \multicolumn{2}{|c|}{ Literacy rate } & \multicolumn{3}{|c|}{ Status of Education } & \multirow[b]{2}{*}{ Total } \\
\hline & $\begin{array}{c}\text { State Average } \\
(2001)\end{array}$ & $\begin{array}{c}\text { Coastal } \\
\text { sector }(2005)\end{array}$ & Primary & Secondary & $\begin{array}{c}\text { Above } \\
\text { secondary }\end{array}$ & \\
\hline West Bengal & 68.64 & 45.65 & $\begin{array}{l}83,301 \\
(67.70)\end{array}$ & $\begin{array}{r}33,734 \\
(27.41)\end{array}$ & $\begin{array}{l}6,018 \\
(4.89)\end{array}$ & $\begin{array}{r}123,053 \\
(100)\end{array}$ \\
\hline Orissa & 63.08 & 47.88 & $\begin{array}{r}142,005 \\
(65.84)\end{array}$ & $\begin{array}{r}56,879 \\
(26.37)\end{array}$ & $\begin{array}{r}16,783 \\
(7.78)\end{array}$ & $\begin{array}{r}215,667 \\
(100)\end{array}$ \\
\hline Andhra Pradesh & 60.47 & 32.47 & $\begin{array}{r}111,403 \\
(67.27)\end{array}$ & $\begin{array}{r}45,827 \\
(27.67)\end{array}$ & $\begin{array}{l}8,384 \\
(5.06)\end{array}$ & $\begin{array}{r}165,614 \\
(100)\end{array}$ \\
\hline Tamil Nadu & 73.45 & 66.75 & $\begin{array}{r}260,088 \\
(49.30)\end{array}$ & $\begin{array}{l}206,257 \\
(39.10)\end{array}$ & $\begin{array}{l}61,229 \\
(11.61)\end{array}$ & $\begin{array}{r}527,574 \\
(100)\end{array}$ \\
\hline Pondichery & 81.24 & 63.18 & $\begin{array}{l}12,763 \\
(46.95)\end{array}$ & $\begin{array}{r}10,904 \\
(40.11)\end{array}$ & $\begin{array}{r}3,518 \\
(12.94)\end{array}$ & $\begin{array}{r}27,185 \\
(100)\end{array}$ \\
\hline Kerala & 90.86 & 72.84 & $\begin{array}{r}171,470 \\
(39.09)\end{array}$ & $\begin{array}{l}218,704 \\
(49.86)\end{array}$ & $\begin{array}{l}48,493 \\
(11.05)\end{array}$ & $\begin{array}{r}438,667 \\
(100)\end{array}$ \\
\hline Karnataka & 66.64 & 69.93 & $\begin{array}{l}52,572 \\
(43.98)\end{array}$ & $\begin{array}{r}49,606 \\
(41.50)\end{array}$ & $\begin{array}{l}17,346 \\
(14.51)\end{array}$ & $\begin{array}{r}119,524 \\
(100)\end{array}$ \\
\hline Goa & 82.01 & 69.12 & $\begin{array}{r}1,691 \\
(22.93)\end{array}$ & $\begin{array}{r}4,581 \\
(62.12)\end{array}$ & $\begin{array}{r}1,102 \\
(14.94)\end{array}$ & $\begin{array}{l}7,374 \\
(100)\end{array}$ \\
\hline Maharashtra & 76.88 & 67.04 & $\begin{array}{l}94,303 \\
(44.04)\end{array}$ & $\begin{array}{r}97,446 \\
(45.51)\end{array}$ & $\begin{array}{l}22,368 \\
(10.45)\end{array}$ & $\begin{array}{r}214,117 \\
(100)\end{array}$ \\
\hline Gujarat & 69.14 & 40.93 & $\begin{array}{l}70,658 \\
(53.40)\end{array}$ & $\begin{array}{r}52,088 \\
(39.37)\end{array}$ & $\begin{array}{l}9,560 \\
(7.23)\end{array}$ & $\begin{array}{r}132,306 \\
(100)\end{array}$ \\
\hline Daman and Diu & 78.18 & 58.28 & $\begin{array}{r}7,760 \\
(45.44)\end{array}$ & $\begin{array}{r}7,273 \\
(42.59)\end{array}$ & $\begin{array}{r}2,045 \\
(11.97)\end{array}$ & $\begin{array}{r}17,078 \\
(100)\end{array}$ \\
\hline Total & 64.84 & 56.50 & $\begin{array}{r}1,008,014 \\
(50.70)\end{array}$ & $\begin{array}{l}783,299 \\
(39.40)\end{array}$ & $\begin{array}{r}196,846 \\
(9.90)\end{array}$ & $\begin{array}{r}1,988,159 \\
(100)\end{array}$ \\
\hline
\end{tabular}


The overall literacy status doubled from $18.57 \%$ in 1980 to $56.50 \%$ in 2005 . The improved socio-economic status of fishers is reflected by increase in literacy level (Table 3 ). The situations in the past have improved that almost half of the population could access education facilities. Among the educated persons, only $20 \%$ were able to have higher education beyond primary level in 1980, whereas at present, the situation has improved that almost half of them study above primary level.

Table 3. Change in educational status of fisher folk in India over the years

\begin{tabular}{lcccccc}
\hline Educational status & Primary & Secondary & $\begin{array}{c}\text { Above } \\
\text { secondary }\end{array}$ & $\begin{array}{c}\text { Not } \\
\text { educated }\end{array}$ & $\begin{array}{c}\text { Total } \\
\text { rate }\end{array}$ \\
\hline 1980 & 280987 & 56998 & 13489 & 1541442 & 1892916 & 18.57 \\
Percentage to total & 14.84 & 3.01 & 0.71 & 81.43 & 100 & \\
2005 & 1008014 & 783299 & 196846 & 1530957 & 3519116 & 56.50 \\
Percentage to total & 28.64 & 22.26 & 5.59 & 43.50 & 100 & \\
\hline
\end{tabular}

Source: Marine Fisheries Census of CMFRI, 1980 and 2005

The overall dependency ratio of marine fisher folk in India is estimated to be 2.04 denoting that every person working in marine fisheries sector supports two persons (Table 4). The dependency ratio varies across the states from 1.56 (Orissa) to 3.88 (Daman and Diu). Among those employed in marine fisheries, most of them are active fishermen, whereas $43.75 \%$ are involved in secondary sector and $4.80 \%$ in tertiary sector.

Table 4. Occupational profile of coastal fisher folk in India (2005)

\begin{tabular}{llllll}
\hline State & \multicolumn{2}{r}{ Number of fisher folk engaged in } & \multicolumn{2}{c}{ Dependency ratio } \\
\hline & Sector & \multicolumn{1}{c}{$\begin{array}{c}\text { Secondary } \\
\text { sector }\end{array}$} & $\begin{array}{c}\text { Tertiary } \\
\text { sector }\end{array}$ & Total & ratio \\
\hline West Bengal & $70,750(54.23)$ & $57741(44.26)$ & $1,968(1.51)$ & $130,459(100)$ & 2.07 \\
Orissa & $121,282(41.94)$ & $152,534(52.75)$ & $15,359(5.31)$ & $289,175(100)$ & 1.56 \\
Andhra Pradesh & $138,614(46.17)$ & $152,892(50.92)$ & $8,727(2.91)$ & $300,233(100)$ & 1.70 \\
Tamil Nadu & $206,908(63.81)$ & $104,509(32.23)$ & $12,817(3.95)$ & $324,234(100)$ & 2.44 \\
Pondichery & $10,341(46.72)$ & $10,095(45.61)$ & $1697(7.67)$ & $22,133(100)$ & 1.94 \\
Kerala & $140,222(62.43)$ & $71,074(31.64)$ & $13,310(5.93)$ & $224,606(100)$ & 2.68 \\
Karnataka & $37,632(41.43)$ & $45,699(50.31)$ & $7,500(8.26)$ & $90,831(100)$ & 1.88 \\
Goa & $2,515(39.30)$ & $3,382(52.85)$ & $502(7.84)$ & $6,399(100)$ & 1.67 \\
Maharashtra & $72,074(43.79)$ & $81,780(49.69)$ & $10725(6.52)$ & $164,579(100)$ & 1.94 \\
Gujarat & $83,322(49.36)$ & $75,082(44.48)$ & $10,390(6.16)$ & $168,794(100)$ & 1.91 \\
Daman and Diu & $5,868(77.73)$ & $1,603(21.23)$ & $78(1.03)$ & $7,549(100)$ & 3.88 \\
Total & $889,528(51.45)$ & $756,391(43.75)$ & $83,073(4.80)$ & $1,728,992(100)$ & 2.04 \\
\hline
\end{tabular}

\footnotetext{
* Figures in parenthesis denote percentage to total
} 


\section{Structural changes in fishing fleets and ownership pattern}

There is a definite trend of decline of non-mechanized boats in recent years. However, there is a clear increase in motorized and mechanized boats due to their better technical efficiency. In mechanized sector itself, growth rate of trawlers is increasing at a faster rate, especially boats with OAL of $15 \mathrm{~m}$ and above, suited for multiday fishing. Many of our existing mechanized boats have now started operating even beyond $100 \mathrm{~m}$ depth resorting to multiday fishing, and the current trend is to go for higher OAL fitted with engines of higher horsepower.

Table 5. Growth rate of marine fishing units in India (1961-1962 to 2004-2005)

\begin{tabular}{|c|c|c|c|c|c|c|c|c|}
\hline \multirow[t]{3}{*}{ Year } & \multicolumn{8}{|c|}{ SECTOR } \\
\hline & \multicolumn{2}{|c|}{ Non mechanized } & \multicolumn{2}{|c|}{ Motorized } & \multicolumn{2}{|c|}{ Mechanized } & \multicolumn{2}{|c|}{ Total } \\
\hline & Number & $\begin{array}{l}\text { Growth } \\
\text { Rate }(\%)\end{array}$ & Number & $\begin{array}{l}\text { Growth } \\
\text { Rate (\%) }\end{array}$ & Number & $\begin{array}{l}\text { Growth } \\
\text { Rate }(\%)\end{array}$ & Number & $\begin{array}{l}\text { Growth } \\
\text { Rate (\%) }\end{array}$ \\
\hline $1961-62$ & 90424 & - & 0 & - & 0 & - & 90424 & - \\
\hline $1973-77$ & 106480 & 18 & 0 & 一 & 8086 & - & 114566 & 27 \\
\hline $1980-81$ & 137000 & 29 & 0 & - & 19013 & 135 & 156013 & 36 \\
\hline 1993-94 & 182096 & 33 & 26171 & & 34571 & 82 & 216667 & 39 \\
\hline $1997-98$ & 160000 & -12 & 32000 & 22 & 47000 & 36 & 239000 & 10 \\
\hline 2004-05 & 104270 & -35 & 75591 & 136 & 58911 & 25 & 238772 & -0.10 \\
\hline
\end{tabular}

The trends indicate the possible phasing out of non-mechanized units at least in certain regions, which ultimately reflected a negative growth of 35\% during 1997-1998 to 2003-2004 (Table 5). This downtrend is compensated in the motorized sector implying large-scale motorization of existing traditional crafts. When the technical efficiency of a particular gear is better than the other, the lesser efficient gears gradually disappear from the operation (Sathiadhas 1998). Mechanized units displayed a major boom during 1980s and 1990s. The growth rates were $135 \%$ and $147 \%$, respectively, in 1980 and 1997 due to diversification and extended area of operation. However, the growth rate of mechanized crafts has reduced to the level of 25\% in 2005 (Table 6).

Table 6. Ownership of fishing units per active fishermen/fishermen households in India

\begin{tabular}{lllll}
\hline Particulars & $1961-62$ & $1973-77$ & 1980 & 2005 \\
Total number of units & 90424 & 114566 & 144030 & 238772 \\
Active fishermen & 229354 & 322532 & 437899 & 1247820 \\
Ownership by active fishermen & 39 & 36 & 33 & 19 \\
\hline
\end{tabular}

Source: Marine Fisheries Census of CMFRI, 1961-1962, 1973-1977, 1980, and 2005 
In the open access marine fisheries, mode of ownership on means of production by fisher folk greatly influences the occupational pattern and socio-economic status. In India, hardly $19 \%$ of active fishermen in marine fisheries sector have ownership on craft and gear in 2005 (Table 6). The proportion of owner operators in marine fisheries declined over the years with the increasing capital requirement for motorized and mechanized fishing units. The ownership of craft and gears by fisher folk declined over the years from $39 \%$ to $33 \%$ (1961-1962 to 1980), and it has sharply reduced to $19 \%$ in 2005. Currently, $14 \%$ in mechanized sector, $19 \%$ in motorized sector, and $25 \%$ in traditional sector have ownership of crafts and gears. This phenomenon is not only due to increasing capital requirement but also due to low disposable income available with fisher folk for investment. Most of the non-motorized units operate as family enterprises not even realizing the full operating cost.

\section{Increasing Capital Investment in Fisheries sector}

Capital investment in marine capture fishery comprises of investment in fishing equipments, which includes hull, engine, gears, and other accessories. The gross capital investment on marine capture fishing sector during 2004-2005 is estimated to be Rs.11,328 crores comprising Rs. 9724 crores in mechanized, Rs. 1009 crores in motorized, and Rs.595 crores in non-mechanized sector (Table 7).

Table 7. Estimated capital investment in crafts and gears in India (1997, 1998 and 2005)

\begin{tabular}{|c|c|c|}
\hline \multirow[t]{2}{*}{ Category } & \multicolumn{2}{|c|}{ Investment (Rs. Crore) } \\
\hline & 1997-1998 & $2004-2005$ \\
\hline \multicolumn{3}{|l|}{ a) Mechanized sector } \\
\hline Trawlers & 1879 & 8289 \\
\hline Purse-seiners & 134 & 189 \\
\hline Gillnetters & 255 & 725 \\
\hline Dolnetters & 49 & 258 \\
\hline Others & 72 & 263 \\
\hline Sub total & 2388 & 9724 \\
\hline \multicolumn{3}{|l|}{ b) Motorized sector } \\
\hline Dugout canoes & 31 & 13 \\
\hline Catamarans & 48 & 89 \\
\hline Plank-built boats & 188 & 455 \\
\hline Others & 188 & 452 \\
\hline Sub total & 456 & 1009 \\
\hline \multicolumn{3}{|l|}{ b) Nonmechanized } \\
\hline Dugout canoes & 218 & 46 \\
\hline Catamarans & 236 & 141 \\
\hline Plank Built Boats & 420 & 396 \\
\hline Others & 49 & 12 \\
\hline Sub total & 923 & 595 \\
\hline Deep sea fishing vessels & 350 & - \\
\hline TOTAL & 4117 & 11328 \\
\hline
\end{tabular}


In India, the ownership of fishing equipments was mostly in private sector. The per capita investment on fishing equipments per active fisherman worked out to Rs. 2,25,651 in 2005 in mechanized sector compared with Rs. 1,25,689 in 1997-1998 (Table 8). In the motorized sector, the per capita investment per active fisherman declined from Rs. 26,835 in $1997-1998$ to Rs. 25,126 in 2005. In case of non-mechanized sector, the per capita investment marginally increased to Rs.14,266 in 2005 from Rs.13,979 in 1997-1998. This can be attributed to the increased proportion of fiber coating on the existing traditional crafts, purchase of FRP boats, and marine plywood boats.

Table 8. Per capita investment on fishing equipments per active fishermen in India 1997-1998 and 2005 (Rs.)

\begin{tabular}{lll}
\hline Sector & $1997-1998^{*}$ & 2005 \\
Mechanized & $1,25,689$ & $2,25,651$ \\
Motorized & 26,835 & 25,126 \\
Nonmechanized & 13,979 & 14,266 \\
Overall & 40,363 & 90,654 \\
\hline
\end{tabular}

\section{Economics of different types of Fishing Units}

Estimated costs and earnings of different craft-gear combinations are given in Table 9. Among the mechanized category, purse seines with $15 \mathrm{mt}$ OAL engaged in multiday fishing (2-5 days) had the highest net operating income per trip (Rs. 42,382) and gross earnings (Rs. 1,15,025). Similarly, the trawlers with single-day operation had the lowest operating income (Rs. 537) among mechanized sector. Among trawlers, the highest gross earnings and net operating income was reported from multiday units (6 and above days). Among gillnets, multidays units ( 6 and above) also reported high earnings.

Within the motorized sector, canoes with ring seines had the highest and plankbuilt boats with gillnet had the lowest net operating income per trip. Catamarans with hooks and lines that operate with minimum costs (Rs. 420) had a lower net income (Rs. 150) in the non-mechanized sector. Dugout canoes/shore seines had the highest income (Rs. 1,250) among non-motorized category. On an average, almost all types of fishing units have a surplus net operating income. However, in each category, there is a number of less efficient units running on losses. Further, for non-mechanized (traditional sector) units, the major component of the operating cost is wages to laborers, which is usually shared depending on gross revenue.

\section{Per Capita Earnings of a Fishing Laborer}

The per capita earnings of a fishing laborer in a year is given in Table 10. It can 
Table 9. Costs and earnings of different craft gear combinations per trip (2003-2004)

\begin{tabular}{|c|c|c|c|c|}
\hline Type of craft-gear combination & $\begin{array}{l}\text { OAL } \\
(\mathrm{mt})\end{array}$ & $\begin{array}{c}\text { Gross Earnings } \\
\text { (Rs) }\end{array}$ & $\begin{array}{l}\text { Operating Costs } \\
\text { (Rs) }\end{array}$ & $\begin{array}{l}\text { Net Operating } \\
\text { Income (Rs) }\end{array}$ \\
\hline \multicolumn{5}{|l|}{ Mechanized } \\
\hline \multicolumn{5}{|l|}{ Trawlers } \\
\hline Single day units & 12 & 2474 & 1937 & 537 \\
\hline Multiday units ( $2-5$ days) & 14 & 23351 & 17648 & 5703 \\
\hline Multiday units (6 and above) & 15 & 44575 & 27934 & 16641 \\
\hline \multicolumn{5}{|l|}{ Gillnetters } \\
\hline Single day units & 10 & 2564 & 1072 & 1492 \\
\hline Multiday units ( $2-5$ days) & 13 & 21054 & 14716 & 6338 \\
\hline Multiday units (6 and above) & 14 & 61870 & 40150 & 21720 \\
\hline \multicolumn{5}{|l|}{ Purseseiners } \\
\hline Single day & 10 & 34682 & 13548 & 21134 \\
\hline Multiday units ( $2-5$ days) & 15 & 115025 & 72643 & 42382 \\
\hline Dolnetter (Single Day) & 13 & 2586 & 1231 & 1355 \\
\hline \multicolumn{5}{|l|}{ Motorized } \\
\hline Plankbuilt Boats with gillnet & 8 & 1950 & 1470 & 480 \\
\hline Canoes with gillnets & 9 & 6590 & 5500 & 1090 \\
\hline Fiber-glass boats with gillnet & 10 & 1490 & 940 & 550 \\
\hline Catamarans with gillnet & 10 & 3530 & 3000 & 530 \\
\hline Canoes with ring seines & 8 & 24000 & 20000 & 4000 \\
\hline Canoes with minitrawl & 7 & 1720 & 1100 & 620 \\
\hline Fiber-glass boats with hooks and & 8 & 2380 & 1160 & 1220 \\
\hline Dingi/bag net units & 10 & 2450 & 1500 & 950 \\
\hline \multicolumn{5}{|l|}{ Non mechanized } \\
\hline Catamarans with gillnet & 4 & 735 & 525 & 210 \\
\hline Fiber-glass boats with gillnet & 9 & 900 & 575 & 325 \\
\hline Dugout canoes/Shoreseines & 8 & 7500 & 6250 & 1250 \\
\hline Catamarans with hooks and Lines & 4 & 570 & 420 & 150 \\
\hline
\end{tabular}

be observed that the physical productivity of worker per unit of capital invested has declined steeply, which is a phenomenon characteristic of the open access resources subject to increased commercialization (Kurien \& Paul 2001). The annual per capita earnings of fishing laborers was the highest for purse seines (Rs. 1,27,200) engaged in multiday fishing (2-5 days) and lowest for trawlers of same category (Rs. 16,800). Although per day earnings per trip were the lowest for single-day trawlers (Rs. 120), their annual earnings were higher than multiday trawler units as they could operate 240 trips in a year $(28,800)$. In case of gillnetters, the annual per capita earnings of the single day units were higher than that of multiday units, although the per capita earnings of multiday units in this category worked out to be the second highest among the 
mechanized units.

Table 10. Per capita earnings of a Fishing Laborer (2003-2004)

\begin{tabular}{|c|c|c|c|}
\hline Type of craft-gear Combination & $\begin{array}{l}\text { Earnings Per } \\
\quad \text { trip (Rs) }\end{array}$ & No. of trips & $\begin{array}{c}\text { Annual } \\
\text { per capita earnings }(\mathrm{Rs})\end{array}$ \\
\hline \multicolumn{4}{|c|}{ Mechanized } \\
\hline \multicolumn{4}{|l|}{ Trawler } \\
\hline Single day & 120 & 240 & 28800 \\
\hline Multiday units (2-5 days) & 280 & 60 & 16800 \\
\hline Multiday units ( 6 and above) & 650 & 36 & 23400 \\
\hline \multicolumn{4}{|l|}{ Gillnetters } \\
\hline Single day & 300 & 240 & 72000 \\
\hline Multiday units (2-5 days) & 350 & 60 & 21000 \\
\hline Multiday units ( 6 and above) & 1680 & 36 & 60480 \\
\hline \multicolumn{4}{|l|}{ Purseseiners } \\
\hline Single day & 500 & 240 & 120000 \\
\hline Multiday units (2-5 days) & 2120 & 60 & 127200 \\
\hline Dolnetter/Dol net (Single day) & 90 & 240 & 21600 \\
\hline \multicolumn{4}{|c|}{ Motorized } \\
\hline Plankbuilt Boats/gillnet & 194 & 230 & 44620 \\
\hline Country crafts/gillnets & 200 & 220 & 44000 \\
\hline Fibreboats/gillnet & 100 & 240 & 24000 \\
\hline Catamarans/gillnet & 150 & 200 & 30000 \\
\hline Countrycrafts/ring seines & 100 & 200 & 20000 \\
\hline Countrycrafts / minitrawl & 75 & 180 & 13500 \\
\hline Fiberboats/hooks and lines & 100 & 240 & 24000 \\
\hline Dingi/bag net & 60 & 220 & 13200 \\
\hline \multicolumn{4}{|c|}{ Nonmechanized } \\
\hline Catamarans with gillnet & 200 & 200 & 40000 \\
\hline Dugout canoes/Shore seines & 100 & 180 & 18000 \\
\hline Country crafts with gillnets & 120 & 240 & 28800 \\
\hline Catamarans with Hooks and Lines & 80 & 240 & 19200 \\
\hline
\end{tabular}

Among the motorized fishing units, plankbuilt boats/gillnets had the highest annual per capita earnings (Rs. 44,620) and the lowest was recorded for dingi/bag net units (Rs. 13,200). Catamarans with gillnet fetched Rs. 40,000 as gross per capita earnings in the year in the nonmechanized (traditional) sector.

\section{Intersectoral disparities in marine fisheries sector}

Every $100 \mathrm{~kg}$ of fish produced from marine fisheries provide full-time employment for 20 persons in the harvesting sector and another 24 persons in the postharvest sector and one person in the tertiary sector. Earlier studies (Sathiadhas et al. 1997) confirmed 
that altogether 10.2 lakhs people are involved in active fishing and 12 lakhs people are involved in preharvest and postharvest sector of marine fisheries during 1995. During 2003-2004, 12.20 lakhs people were employed in active fishing in the primary sector and another 15 lakhs in the preharvest and postharvest sector in the secondary sector, and one lakh people were employed in the tertiary sector. The recent estimates have confirmed that 12.49 lakhs people are employed in the primary sector. The Marine Fisheries Census of CMFRI, 2005 has estimated that 8.89 lakhs people are involved in active fishing alone in the coastal villages of India. According to the Marine Fisheries Census of 2005, there are 58911 mechanized units, 75591 motorized units, and 104270 nonmechanized (traditional) units. Average number of sea faring persons is 6 in a trawler, 9 in a Gillnetter, 20 in purse seiners and liners, 5 in dolnetters, and 9 in others. In case of motorized units, the number of persons range from 2 in a motorized catamaran to 40 in shore seiners, and the average number is assumed to be 5 . In case of nonmechanized (traditional sector) units, number of crew varies between 2 for catamaran to 44 for shore seiners. The average number of crew in nonmechanized (traditional sector) craft is assumed to be 4 . Thus, it is estimated that additional 3,60,060 persons are also involved in active fishing from adjacent areas to the coastal belt.

The proportion of catch by mechanized sector as a whole increased from $40 \%$ during 1980 to 68\% in 1997 and again declined to 66\% in 2003 (Table 9). Currently, the share of mechanized sector is $70 \%$ of the catch. At the same time, the number of active fishermen depending on mechanized fisheries increased from 1.14 lakhs to 2 lakhs and again increased to 4.3 lakhs, respectively, during the same period. It should be noted that the annual per capita production of active fisherman during the period has initially increased from $5260 \mathrm{~kg}$ in 1980 to $8130 \mathrm{~kg}$ in 1997 and declined to 4175 in 2003 and $3701 \mathrm{~kg}$ in 2005 . It is highly evident that the increase in share of production in the sector is taken away by the increase in number of crafts and proportionate increase in the number of fisher folk depending on the sector. The annual average production per unit has come down to an all time low value of 27 tonnes. This clearly indicates the high prevalence of disguised unemployment in the mechanized fisheries sector.

In motorized segment also, the similar trend was observed. The annual production per unit is declining over the years from 13 tonnes in 1997-1998 to 7 tonnes in 2005. In case of annual per capita production per active fisherman, it almost halved to $1320 \mathrm{~kg}$ in 2005 from $2390 \mathrm{~kg}$ in 1997-1998. The ownership of means of production per active fisherman regained its earlier position in 2005 (19\%) after a decline to $12 \%$ in 2003-2004. The nonmechanized (traditional sector) segment has experienced significant reduction in the share of production as well as gross earnings. The share of nonmechanized (traditional sector) sector in marine fish production reduced from $60 \%$ in $1980-1981$ to $7 \%$ in 2005 . Similar trend was observed in case of average annual production with a decrease from 6.57 tonnes in $1980-1981$ to 1.6 tonnes in 2005 . The 
Table 11. Structural changes in socio-economic parameters in non-mechanized, motorized, and mechanized sector (1980-1981 to 2005)

\begin{tabular}{lccc}
\hline Item & 1980 & 1997 & 2004 \\
& -1981 & -1998 & -2005 \\
\hline Mechanized & & & \\
Marine fish production (\%) & 40 & 68 & 70 \\
Average annual production per unit (in tonnes) & 32 & 33 & 27 \\
Annual per capita production/active fishermen (in Kg) & 5260 & 8130 & 3701 \\
Ownership of means of production by active fishermen (\%) & 17 & 24 & 14 \\
Active fishermen & 114000 & 200000 & 430931 \\
Motorized & & & \\
Marine fish production (\%) & - & 19 & 23 \\
Average annual production per unit (in tonnes) & - & 13 & 7 \\
Annual per capita production/active fishermen (in Kg) & - & 2390 & 1320 \\
Ownership of means of production by active fishermen (\%) & - & 19 & 19 \\
Active fishermen & - & 170000 & 401577 \\
Nonmechanized (traditional sector) & & & \\
Marine fish production (\%) & 60 & 13 & 7 \\
Average annual production per unit (in tonnes) & 6.57 & 1.7 & 1.6 \\
Annual per capita production/active fishermen (Kg) & 2590 & 420 & 408 \\
Ownership of means of production by active fishermen (\%) & 39 & 25 & 25 \\
Active fishermen & 348000 & 650000 & 415312 \\
Total & & & \\
Average annual production per unit (in tonnes) & 9.6 & 9.6 & 9.6 \\
Annual per capita production/active fishermen (in Kg) & 3247 & 2254 & 1837 \\
Ownership of means of production by active fishermen (\%) & 34 & 23 & 19 \\
Active fishermen & 462000 & 1020000 & 1247820 \\
\hline
\end{tabular}

annual per capita production per active fisherman suffered utmost decline from $2590 \mathrm{~kg}$ in 1980-1981 to $408 \mathrm{~kg}$ in 2005 . There has been a slight increase in ownership of means of production by active fishermen in 2005 (25\%) after a steep decline from $39 \%$ in 1980-1981 to $21 \%$ in 2003-2004. The pressure for employment in active fishing is increasing more than proportionate to the harvestable yield in the open access marine fisheries. The fishermen involved in fishing is more than the absorbing capacity and has led to lower per capita production, juvenile fishing, and large scale discards and causes serious threats to resource sustainability and environmental stability. Further intensive mechanization in the marine sector has led to increase in production but has ultimately marginalized the traditional nonmechanized (traditional) sector. There is a wide disparity in income between those engaged in different sectors. It may be noted that still nonmechanized sector is providing about $33 \%$ of the employment in active 
fishing, yet harvesting hardly $7 \%$ of the annual landings, whereas mechanized segment, which employs $34 \%$ harvests $70 \%$ of total catch. The annual per capita catch of fisher folk in mechanized segment is more than twice as that of the per capita catch of the motorized segment and nine times of the per capita catch of the nonmechanized (traditional sector) segment. These phenomenon results in marginalization of the indigenous nonmotorized sector by the motorized and mechanized sectors and frequently create conflicts among fishers.

Employment in fisheries sector has undergone rapid structural changes during the last few decades. Among those engaged in the mechanized sector, $75 \%$ work in trawl fisheries and the remaining $25 \%$ in other sectors. In the case of motorized sector, $50 \%$ are engaged in ring seine fishery alone. There is a wide intrasectoral disparity in income between those engaged in various craft gear combinations within each sector. The number of annual fishing days per worker reveals that the level of employment for hired laborers as well as those not having sufficient equipment is low and they are very much underemployed. The seasonal nature of fishery and the risk and uncertainties associated with marine fishing entangled the fishermen in the low-income trap. The poor economic condition coupled with the less availability of finance from the institutional agencies compel them to sustain with less equipped fishing implements, which in turn results in diminishing returns (Table 11).

\section{Conclusion}

Marine fishing industry in India has continuously recorded increase in private capital investment. The private capital investment on fishing equipments alone increased from about Rs. 4117 cores in 1997-1998 to Rs. 11, 328 cores in 2004-2005. The labor class in active fishing is increasing more than proportionate to their demand resulting in disguised unemployment. It is seen that hardly $19 \%$ of the active fishermen in India have ownership of fishing implements. Inequitable distribution of income is continuously increasing, further widening the gap between the rich and poor in the coastal economy. Along with the mounting inequity in harvesting open access resources, there are constraints like depletion of resources necessitating conservation strategies to sustain the marine wealth. In this context, policy interventions are essential to provide alternative avocations in agriculture, aquaculture, and other coastal-zone-based employment opportunities instead of increasing pressure to harvest more and more marine fish resources. Finance plays a crucial role in accelerating any business activity/economic development, and fisheries sector is not an exception. The extent of indebtedness and the average outstanding debt per indebted households are comparatively less among fishermen as per the figures of institutional sources, but the affairs of the fisher folk are really grim as they are virtually gripped in the hands of noninstitutional agencies, namely the money lenders and traders for which legitimate data sources do not exist. This is because of the inherent problems in the functioning of the institutional agencies, which need to be reviewed. Special coastal area development programs offering easy credit 
availability for entrepreneurial activities for the surplus labor may check the disguised unemployment, intersectoral disparity, and poverty among the coastal fisher folk in India.

\section{Acknowledgements}

I hereby express my sincere thanks to Prof. (Dr). Mohan Joseph Modayil, Director, CMFRI, Kochi, for his kind encouragement and support for preparation of this article.

\section{References}

Amarasiri Desilva, M.W. 1977. Structural Change in a coastal fishing community in Southern Sri Lanka. Quarterly Journal 4(2):67-68.

$$
\text { Marga }
$$

Desai, M.B. and P.R. Baichwal. 1960. Economic Survey of Fishing Industry in Thana District. Bombay, India. In: The Economic Role of Middlemen and Cooperatives in Indo-pacific Fisheries (ed. E.F Szezepanic). FAO, Rome

George, P.C. 1974. Fisheries Planning and Development in India. Proceedings of Indo-Pacific Fisheries 16(3), Bangkok. Council,

Gurtner, P. 1960. Development of Boat for India's Surf Coasts: In Fishing Boats of the World-2 (ed. J.O.Traung).

Fishing News (Books) Ltd., London.

John Kurien and Antonyto Paul. 2001. Social Security Nets for Marine Fisheries, Working Paper, No 318, Centre for Development studies, Thiruvananthapuaram.

Korakkandy Ramakrishnan. 1994. Technological change and the development of marine fishing industry in India - a case study of Kerala. Daya Publishing House, Delhi., 1-338 pp.

Krishna Srinath. 1987. Role of women in small scale fisheries - a case study. Marine Fisheries Information Services. T\&E.Ser 72:12-17.

Lawson, R. M. 1977. New directions in developing small-scale fisheries. Marine Policy 1(1):45-51.

Panikkar, K.K.P. 1980. Coastal rural indebtedness - a case study. The Marine fisheries Information Service. Technical and Extension Series 18:8-12.

Pietersz, S. 1983. Possibilities for improving the quality of life of small-scale fishermen in the Bay of Geography Teacher. 18 (2\&3) 21-43

Platteau, J. Ph. 1984. The drive towards mechanisation of small scale fisheries in Kerala: a study of the transformation of traditional villages societies. Development and Change, 15, London.

Prakasam, M.S. 1974. Impact of mechanisation on fishermen. Voluntary Action, 16 (2\&3) March-June: 13-

19. Prasada Rao, D.L and R.Y. Kumar, 1984. Impact of mechanisation on a traditional economy: a case study of fishermen

in Visakhapatnam. Man and Life 10(1\&2):31-42.

Sathiadhas, R and G. Venkitaraman, 1981. Impact of mechanised fishing on socio-economic conditions of the fishermen of Sakthikulangara - Neendakara, Kerala. The Marine fisheries Information Service. Technical and Extension Series 29:1-18.

Sathiadhas, R and K.K.P. Panikkar. 1988. A study on marketing structure and price behaviour of marine fish in Tamil Nadu. Sea Food Export Journal 20(12):5-29.

Sathiadhas, R. 1998. Socio-economic structural changes in the marine fisheries sector of India and coastal zone management. Proceedings of seminar on coastal zone management. 79-89.

Sathiadhas, R., R. Reghu and Sheela Immanuel. 1997. Human resource utilisation, productivity, and earnings in Indian marine fisheries. Sea Food Export Journal 30(4):51-55.

Selvaraj, C 1975. Small fishermen in Tamil Nadu. Madras Institute of Development Studies, Publication No.9. Sangam Publishers, Madras

Sen Amartya, 1973. Poverty, inequality and unemployment - some conceptual issues in measurement. Economic and Political Weekly 16(14), 1950

Shanbhu Dayal, 1981. Negative effects of mechanisation. The Economic Times, (Suppl.) 21 February, 10:8. 